\title{
Twenty-five Statements on Early Initiation of Fixed Combination ICS/LABA Treatment for Asthma and COPD in Primary and Secondary Care: Consensus Research by a Modified Delphi Process
}

Frühzeitiger Einsatz einer ICS/LABA Fixkombinationstherapie in der Versorgung von Asthma- und COPDPatienten in der Praxis: Fünfundzwanzig Konsensus-Statements aus einem modifiziertem Delphi-Prozess

Authors

Institutions
P. Kardos ${ }^{1}$, B. Bechtel ${ }^{2}$, L. Palovis ${ }^{3}$, C. Hagedorn ${ }^{3}$, F. Latif ${ }^{4}$

Institutions are listed at the end of article. received 10.4.2012

accepted 26.6.2012

\section{Bibliography}

Dol http://dx.doi.org/

10.1055/s-0032-1310076

Published online: 16.8 .2012

Pneumologie 2012; 66: 549-557

(c) Georg Thieme Verlag KG

Stuttgart · New York

ISSN 0934-8387

\section{Corresponding author}

Dr. med. Peter Kardos

Scheffelstrasse 33

60318 Frankfurt am Main

Germany

Kardos@lungenpraxis-

maingau.de

\section{Abstract \\ $\nabla$}

Background: Guidelines recommend the addition of a long-acting $\beta_{2}$-agonist (LABA) for patients whose asthma is uncontrolled on inhaled corticosteroid (ICS) monotherapy. For COPD patients the addition of an ICS to a long-acting bronchodilator is recommended for symptomatic patients at high risk of exacerbations. We examined whether in real-life practice guideline recommendations may delay optimal timing for initiation of combination treatment.

Methods: A modified Delphi process was undertaken with a panel of physicians, including six GPs and four pulmonologists, in practice in Germany. The first round comprised a semi-structured questionnaire, the second stage was an online discussion to reach consensus on 25 statements concerning the use of ICS/LABA in patients with asthma or COPD.

Results: Consensus was achieved on 24 of 25 prepared statements for early initiation of fixed ICS/ LABA combination treatment. The panel agreed that a meaningful share of their asthma patients on ICS monotherapy experienced symptoms and exacerbations that should lead to addition of LABAs and that timely initiation of ICS/LABA therapy in asthma patients could improve asthma control, and prevent a significant number of emergency room visits, hospitalisations or additional specialist visits. The panel agreed that symptomatic patients with moderate to severe COPD, and frequent exacerbations should receive ICS without any delay in addition to their bronchodilator maintenance therapy. These patients could benefit from fewer exacerbations and a reduction in symptoms. The panel reached a consensus that fixed-dose ICS/LABA could have a positive effect on adherence, compared with separate inhalers for ICS and LABA, which may impact treatment outcomes.

\section{Zusammenfassung \\ $\nabla$}

Hintergrund: Zur Behandlung von Patienten, deren Asthmasymptome durch den Einsatz inhalativer Kortikosteroide (ICS) nicht kontrolliert werden können, empfehlen Leitlinien die zusätzliche Gabe eines langwirksamen $\beta 2$-Agonisten (LABA). Für COPD-Patienten mit hohem Exazerbationsrisiko wird ergänzend zur LABA-Monotherapie der Einsatz von ICS empfohlen. Die vorliegende Untersuchung konzentriert sich auf die Frage, ob in der Alltagspraxis die gegenwärtige Leitlinienempfehlung den Einsatz von Kombinationstherapien verzögert.

Methodik: Die Basis des modifizierten DelphiProzesses bildet ein Panel, aus sechs Allgemeinärzten und vier Pneumologen zusammengesetzt, geografisch über Deutschland verteilt. Der erste Abschnitt des Prozesses stellte die Beantwortung eines teilweise strukturierten Fragebogens dar. In einem zweiten Schritt wurden die Teilnehmer mit aus den Fragebögen erstellten Konsensaussagen konfrontiert, über deren Inhalt wurde diskutiert und abgestimmt.

Ergebnisse: Ein Konsens konnte bei 24 von 25 Aussagen zum frühen Einsatz der fixen Kombinationstherapie mit ICS/LABA erreicht werden. Das Panel war sich dahingehend einig, dass ein bedeutender Anteil der von ihnen behandelten Asthmapatienten unter Monotherapie mit ICS an Symptomen und Exazerbationen leidet, was für eine ergänzende Therapie mit LABA spricht. Der frühzeitige Einsatz einer ICS/LABA-Kombinationstherapie bei diesen Asthma-Patienten verspricht eine Optimierung der Asthmakontrolle sowie eine erhebliche Reduktion der Notfallbehandlungen, Krankenhausaufenthalte oder Besuche beim Facharzt. Bei COPD-Patienten mit moderaten bis schweren Symptomen sowie häufigen Exazerbationen sollte umgehend eine Ergänzung der LABA-Therapie mit ICS initiiert werden. Als Vor- 
Conclusion: A panel of ten physicians working in primary and secondary care agreed on 24 out of 25 statements that supported the early initiation of fixed combination treatment, if indicated in a meaningful number of their asthma and COPD patients. teile der frühen Initiierung einer Kombinationstherapie bei solchen Patienten bestand Konsens hinsichtlich der verringerten Häufigkeit von Exazerbationen sowie der Verringerung der Symptomlast. Darüber hinaus bestand Konsens darin, dass der Einsatz einer fixen Kombinationstherapie mit ICS/LABA, im Vergleich zu getrennt verabreichten ICS- und LABA-Inhalatoren, positive Auswirkungen auf die Adhärenz haben kann und damit das Behandlungsergebnis positiv beeinflusst.

Schlussfolgerung: Über 24 der 25 vorgeschlagenen Aussagen zum frühzeitigen Einsatz einer Kombinationstherapie mit ICS und LABA in der Behandlung von COPD- und Asthma-Patienten konnte ein Konsens erzielt werden. Das Panel unterstützte einen frühzeitigen Einsatz der Kombinationstherapie bei einem bedeutenden Anteil der von ihm behandelten Asthma- und COPD-Patienten.

The treatment strategies for both asthma and COPD employ a stepwise approach, and the range of medications shows considerable overlap. Although there are some differences in treatment goals, the prevention and treatment of symptoms and exacerbations are common aims for both conditions $[4,5]$.

NVL guidelines for asthma, and those of GINA, recommend a lowdose inhaled corticosteroid (ICS) as the initial controller medication at treatment Step 2. In the NVL guideline, there is an important controversy over the escalation of therapy at Step 3; the majority recommendation of the NVL was for doubling the ICS dose, however, the German Respiratory Society voted for the early addition of a long-acting $\beta_{2}$ agonist (LABA), either in separate inhalers, or in a combined delivery device (fixed-dose combination) ( $\bullet$ Fig. 1) [4]. The decision to adjust step-up (or step-down) treatment is made on the level of patient's asthma control $[4,8]$.

\section{are consistent with the principal international standards of} Global Initiative for Asthma (GINA) and the Global Initiative for Chronic Obstructive Lung Disease (GOLD) $[8,9]$.

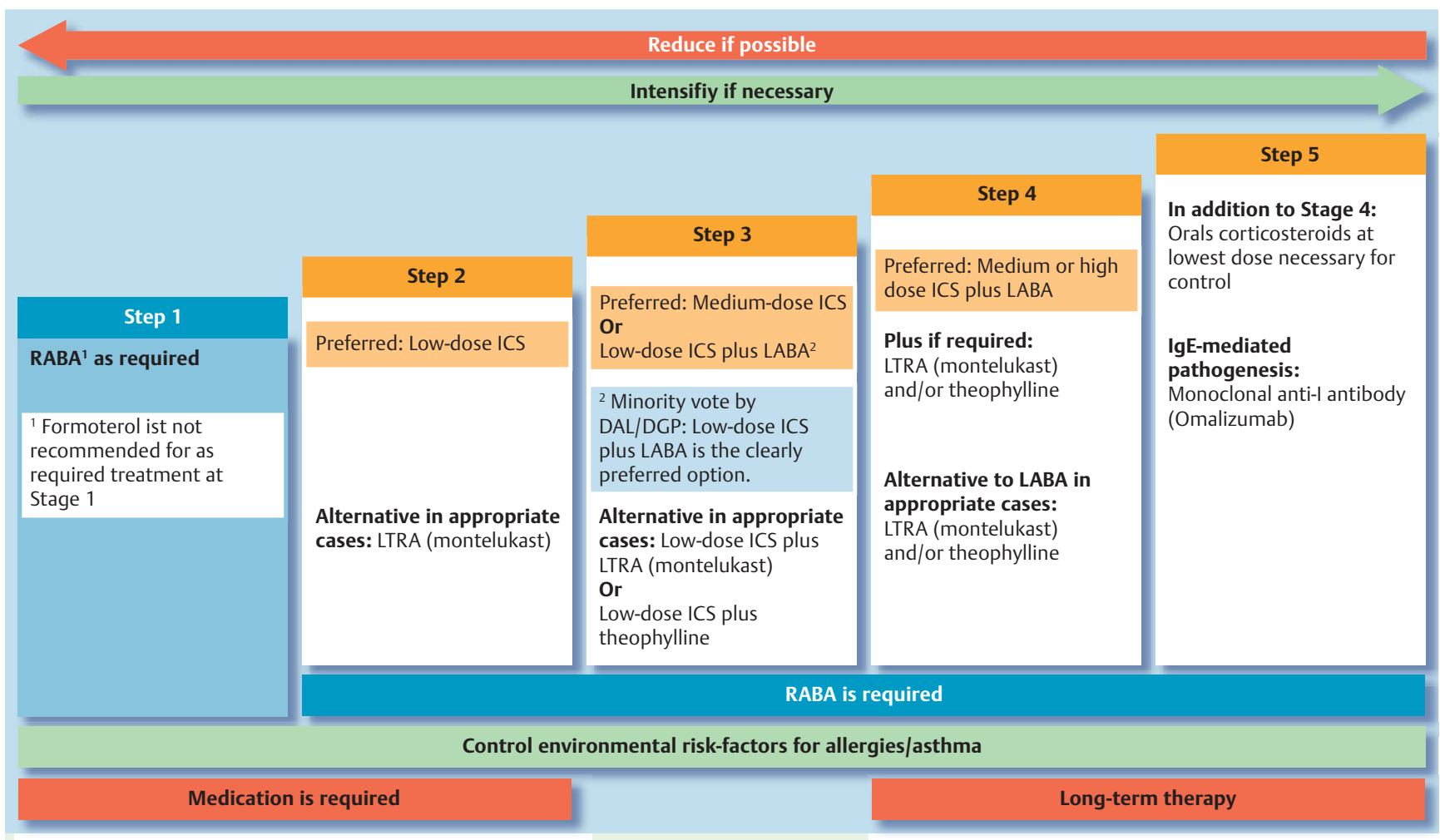

Fig. 1 NVL guideline: medication for the long-term therapy of asthma in adults [4]. ICS = inhaled corticosteroid, LRTA=leukotriene receptor antagonist, DAL/ DGP= Deutsche Atemwegsliga/Deutsche Gesellschaft für Pneumologie (German Airways League/German Respiratory Society), RABA= rapid-acting beta-agonist. Adapted; from: Nationale VersorgungsLeitlinien Asthma: Available at: http://www.versorgungsleitlinien.de/themen/asthma. 
The treatment of COPD patients should be based on the following step-by-step plan:

\section{Step IV: $\mathbf{3 0} \% \leq \mathrm{FEV}_{1}$ predicted, or respiratory insufficiency}

Avoid risk factors* Immunisation** Rehabilitation measures****

Rapid-acting bronchodilator*** as required; one or more long-acting bronchodilators*** as long-term therapy (alone or in combination). ICS (in cases of repeated exacerbations). Consider other measures

(long term oxygen therapy, surgery)

\section{Step III: $\leq \mathbf{3 0} \%$ FEV $_{1}<50 \%$ predicted}

Avoid risk factors*

Immunisation**

Rehabilitation measures $* * * *$

Rapid-acting bronchodilator*** as required; one or more long-acting bronchodilators ${ }^{* * *}$ as long-term

therapy (alone or in combination). ICS (in cases of repeated exacerbations)
Fig. 2 NVL guideline; therapy for stable COPD [5]. * Avoid inhalation of irritants (especially tobacco smoke), ** vaccination against influenza and pneumococcal disease, ${ }^{* * *}$ beta -agonists and/or anticholinergics (antimuscarinics); theophylline is third

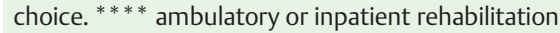
and/or non-drug measures such as physical exercise, physiotherapy and patient education. Adapted; from: Nationale VersorgungsLeitlinien COPD: Available at: http://www.versorgungsleitlinien.de/ themen/COPD.

\section{Step II: $\leq \mathbf{5 0} \% \mathrm{FEV}_{\mathbf{1}}<\mathbf{8 0} \%$ predicted}

Avoid risk factors*

Immunisation**

Rehabilitation measures****
Rapid-acting bronchodilator*** as required; one or

more long-acting bronchodilators as long-term therapy

(alone or in combination).

Step I: $\geq 80 \%$ FEV $_{1}<70 \% \mathrm{FEV}_{1} / \mathrm{FVC}$

Rapid-acting bronchodilator*** as required

Despite the availability of effective treatments and full reimbursement, a high proportion of patients has asthma that is not well controlled. In Germany, it was estimated from the European National Health and Wellness Survey that almost twothirds (65.3\%) of people with asthma were uncontrolled [10], according to the criteria of the Asthma Control Test (ACT) [11].

The current NVL (2007) recommendations for the pharmacological treatment of COPD are based on four stages defined by airflow limitation with the option of introducing an ICS to long-acting bronchodilator therapy at Grade III (where $\mathrm{FEV}_{1}<50 \%$ ), in patients with repeated exacerbations ( $\bullet$ Fig. 2 ) [5]. However, the label of the salmeterol plus fluticasone fixed-dose combination is for $\mathrm{FEV}_{1}<60 \%$ [12]. In the most recent GOLD guideline (2011), published after the Delphi research was conducted, the approach to pharmacological treatment of COPD has changed and is now based on a combined assessment of severity of COPD, which includes the risk of exacerbations and symptoms assessed by validated questionnaires. Assessment of airflow limitation should be used as a complementary tool beside the patient's history, to assess exacerbation risk [9].

COPD exacerbations, particularly those that lead to hospitalisation account for the greatest proportion of costs [5].

This paper reports on research we conducted using a modified Delphi process with a panel of physicians in primary and secondary care in Germany, who regularly manage patients with asthma and COPD. The aim of this Delphi panel was to investigate real-life clinical practice in the use of ICS/LABA in the management of asthma in primary and secondary care in Germany. It aimed to investigate whether such treatments are employed, based on the clinical judgement of experienced physicians and how the real clinical use matches the guidelines.

\section{Methods}

This research was commissioned by GlaxoSmithKline (GSK) to Double Helix Consulting (DHC) who recruited participants, performed all research, conducted the analysis and drafted the manuscript in accordance with a structure devised by the leading author.

\section{The Delphi process}

The study used a modified Delphi process to develop a series of consensus statements on the use of combination ICS/LABA therapy in patients with asthma and/or COPD derived not only from the guidelines, but also the routine practice by experienced GPs and specialists.

The Delphi process is a validated consensus development methodology that enables a group of experts to deal with a complex problem through a structured group communication process. The process was devised by Dalkey and Helmer at the RAND Corporation in the 1950s [13]. Its name is taken from the Oracle at Delphi in Ancient Greece. The method has been successfully employed in business and military applications, and now Delphi processes are increasingly used in published biomedical studies. There is evidence that the technique has been utilised in several hundred published papers [14]. Furthermore, most guidelines are developed by a modified Delphi process, for example, the asthma and COPD guidelines of the German Respiratory Society $[4,5]$.

The method is based on the assumption that group judgments can be more valid than individual judgments. It uses an iterative process of questioning; in each round of the Delphi process, individual judgments are collected and summarised by an independent facilitator, who presents them for the next round, with the goal of achieving consensus, as results are shared and responses are adjusted. It is not necessary to achieve 'perfect' consensus; the goal is to identify as many statements as possible to which 
Table 1 Physicians recruited for Delphi process consensus panel

\begin{tabular}{|c|c|c|c|c|c|c|}
\hline \multirow[t]{2}{*}{ Physician } & \multirow[t]{2}{*}{ Clinical role } & \multirow[t]{2}{*}{ Location } & \multicolumn{2}{|c|}{ Average No. Patients Month } & \multirow{2}{*}{$\begin{array}{l}\text { Patients prescribed ICS/LABA } \\
\text { fixed-dose combination }\end{array}$} & \multirow{2}{*}{$\begin{array}{l}\text { Prescribing step-up according } \\
\text { to GINA/GOLD guidelines }\end{array}$} \\
\hline & & & Asthma & COPD & & \\
\hline 1 & GP & Rhein-Neckar & 40 & 150 & $75 \%$ & Yes \\
\hline 2 & GP & Berlin & 45 & 35 & $80 \%$ & Yes \\
\hline 3 & GP & Hannover & 80 & 150 & $60 \%$ & Yes \\
\hline 4 & GP & Heidelberg & 40 & 80 & $70 \%$ & Yes \\
\hline 5 & GP & Coburg & 40 & 40 & $80 \%$ & Yes \\
\hline 6 & GP & Munich & 20 & 40 & $30 \%$ & Yes \\
\hline 7 & Pulmonologist & Frankfurt & NR & NR & NR & NR \\
\hline 8 & Pulmonologist & Ulm & NR & NR & NR & NR \\
\hline 9 & Pulmonologist & Schwedt & NR & NR & NR & NR \\
\hline 10 & Pulmonologist & Frankfurt & NR & NR & NR & NR \\
\hline
\end{tabular}

$\mathrm{NR}=$ information not requested at time of recruitment. Pulmonologists were assumed to treat to the guidelines.

the highest number of panellists can agree within a pre-specified range.

Traditional focus groups or advisory boards can be difficult to manage, anonymity can be violated, 'vocal' versus 'reserved' participants, and power dynamics could skew the outcomes of such groups. Delphi survey methods can be used in scenarios where accurate information is unavailable, or would be resource-prohibitive to obtain and human opinions are critical.

A workshop with an interdisciplinary team devised a questionnaire on the use of ICS and LABA that could be put to a panel of physicians. In the first round of the process panellists completed the questionnaire, which comprised three sections; 36 questions on the number of asthma patients attending the physician's practice each month; 30 questions on the number of COPD patients seen; and nine questions on the prescribing and use of ICS/LABA combination therapy as separate inhalers and in fixed-dose combination inhalers, i.e., fluticasone/salmeterol or budesonide/formoterol. The questions on asthma and COPD patients asked about the characteristics of these patients with regard to disease severity, signs and symptoms, and the therapeutic choices made. The questionnaire, which drew on the experience of primary care physicians and pulmonologists regularly involved in the management of asthma and COPD patients, was used to develop 25 radical statements concerning the early use of ICS/LABA combination therapy.

The second stage was a mediated meeting of approximately 4 hours duration by online videoconference with participants visible to each other by web cam on 24 November 2011. The discussion aimed to arrive at consensus on the 25 statements addressing issues raised in the questionnaire. For the current study it was specified that a majority of 7 out of 10 was necessary for consensus to be arrived at, and statements were modified where necessary to achieve consensus.

\section{Constitution of panel}

The panel comprised ten physicians, four pulmonologists and six general practitioners (GPs), in clinical practice in Germany, who were regularly involved in the management of outpatients with asthma or COPD. The physicians were recruited from different locations across Germany, to provide a snapshot of clinical practice in the management of obstructive airways disease across the country both in primary and specialist care ( $\bullet$ Table $\mathbf{1})$.

Pulmonologists were recruited by DHC, at random from a GSK list of pulmonologists practicing in Germany. There was no pre-se- lection of potential participants, and the physicians had no financial or other connections with GSK or DHC.

GPs were recruited by a third party specialist recruitment agency based in Germany, commissioned by DHC. These physicians had no financial or other connections with GSK or DHC.

When recruiting GPs it was established that they regularly managed asthma and COPD patients in their practices, and that they followed the principles of current German guidelines (both NVL and the German Respiratory Society), and of the international GOLD and GINA guidelines ( $\bullet$ Table $\mathbf{1}$ ). At recruitment the GPs reported that they saw between $20-80$ asthma patients a month and 35-150 COPD patients ( $\bullet$ Table 1 ). At recruitment, pulmonologists were not asked about their patient numbers.

\section{Results \\ $\nabla$}

In the results of the questionnaire, GPs reported that they saw 20 - 83 asthma patients a month at their practices and pulmonologists reported that they saw between $20-250$ asthma patients. GPs saw an average of 40-150 COPD patients a month at their practices and pulmonologists saw an average of 100-200 COPD patients ( $\bullet$ Table 2). The GPs reported that $30-75 \%$ of patients had uncontrolled asthma at the time of presentation, and the pulmonologist reported that $50-70 \%$ of their asthma patients were uncontrolled. GPs reported that approximately $29 \%$ of their COPD patients had moderate COPD and $12 \%$ had severe or very severe COPD. The pulmonologists estimated that $45 \%$ of their COPD patients had moderate COPD and $23 \%$ had severe or very severe COPD ( $\bullet$ Table 2). Physician usage of medication is summarised in $\bullet$ Table 2.

\section{Consensus statements on asthma}

After discussion consensus was reached on 24 statements given in detail in $\bullet$ Table 3, $\odot$ Table 4 and $\odot$ Table 5. The panellists agreed that they had a high proportion of asthma patients on ICS monotherapy presenting with symptoms or exacerbations that would met the guideline recommendations for dose escalation. It was agreed that early initiation of combination ICS/LABA therapy would reduce the risk of exacerbations and improve control, which would lead to reduced health care utilisation in terms of additional specialist visits, emergency room visits and hospitalisations. They also reached a consensus that asthma patients on ICS/LABA fixed-dose combination (FDC) therapy were more adherent than patients on free combination ICS + LABA, which 
Table 2 Physician background - from questionnaire

\begin{tabular}{|c|c|c|c|c|c|c|c|c|c|c|}
\hline \multirow[t]{3}{*}{ Physician } & \multirow[t]{3}{*}{ Speciality } & \multicolumn{7}{|c|}{ Average No. Patients Month } & \multirow{3}{*}{$\begin{array}{l}\text { Asthma patients } \\
\text { prescribed } \\
\text { ICS/LABA fixed- } \\
\text { dose combination }\end{array}$} & \multirow{3}{*}{$\begin{array}{l}\text { COPD patients } \\
\text { prescribed } \\
\text { ICS/LABA }\end{array}$} \\
\hline & & \multicolumn{3}{|c|}{ Asthma } & \multicolumn{4}{|c|}{ COPD } & & \\
\hline & & $\mathbf{N}$ & $\begin{array}{l}\text { Con- } \\
\text { trolled }\end{array}$ & $\begin{array}{l}\text { Uncon- } \\
\text { trolled }\end{array}$ & $\mathbf{N}$ & Mild ${ }^{1}$ & $\begin{array}{l}\text { Moder- } \\
\text { ate }^{1}\end{array}$ & $\begin{array}{l}\text { Severe or } \\
\text { very severe }{ }^{1}\end{array}$ & & \\
\hline 1 & GP & 40 & $70 \%$ & $30 \%$ & 150 & 60 & 30 & 10 & $40 \%$ & NS \\
\hline 2 & GP & 35 & $70 \%$ & $30 \%$ & 45 & 25 & 18 & 2 & $80 \%$ & $50 \%$ \\
\hline 3 & GP & $83^{2}$ & $25 \%$ & $75 \%$ & $144^{2}$ & $70^{2}$ & $50^{2}$ & $24^{2}$ & $70 \%$ & $35 \%$ \\
\hline 4 & GP & 50 & $60 \%$ & $40 \%$ & 100 & 60 & 30 & 10 & $70 \%$ & $10 \%$ \\
\hline 5 & GP & 40 & $70 \%$ & $30 \%$ & 40 & 10 & 20 & 10 & $20 \%$ & $30 \%$ \\
\hline 6 & GP & 20 & $30 \%$ & $70 \%$ & 40 & 25 & 10 & 5 & $25 \%$ & $10 \%$ \\
\hline 7 & Pulmonologist & 250 & $30 \%$ & $70 \%$ & 200 & 100 & 60 & 40 & $150 /$ month & 30 \\
\hline 8 & Pulmonologist & 30 & $67 \%$ & $33 \%$ & 100 & 20 & 70 & 10 & $30 \%$ & NS \\
\hline 9 & Pulmonologist & 80 & $50 \%$ & $50 \%$ & 100 & 10 & 50 & 40 & $50 /$ month & 40 \\
\hline 10 & Pulmonologist & 20 & $50 \%$ & $50 \%$ & 100 & 30 & 40 & 30 & $10 \%$ & NS \\
\hline
\end{tabular}

NS $=$ not stated.

${ }^{1}$ Categorised according to NVL criteria.

${ }^{2}$ Approximate, physician supplied 3-month data.

Table 3 Consensus statements on asthma

\begin{tabular}{|c|c|c|}
\hline & Consensus statement & Additional comments \\
\hline \multirow[t]{2}{*}{$\begin{array}{l}\text { Presenting signs } \\
\text { and symptoms }\end{array}$} & $\begin{array}{l}\text { - A significant share of asthma patients treated with ICS monotherapy } \\
\text { experience one or more symptoms that would, depending on their } \\
\text { severity, make you consider escalating their treatment (such as breath- } \\
\text { lessness or exacerbations). }{ }^{1}\end{array}$ & \\
\hline & $\begin{array}{l}\text { - A significant proportion of asthma patients on ICS monotherapy do } \\
\text { not consult you when they experience symptoms that would make you } \\
\text { consider escalating their treatment. }{ }^{1}\end{array}$ & \\
\hline \multirow[t]{4}{*}{$\begin{array}{l}\text { Exacerbations and } \\
\text { their management }\end{array}$} & $\begin{array}{l}\text { - Approximately, } 30 \text { - } 50 \% \text { of Patients on ICS monotherapy could experi- } \\
\text { ence, on average, two to three exacerbations per year. }\end{array}$ & \\
\hline & $\begin{array}{l}\text { - Early initiation onto ICS/LABA therapy can improve asthma control and } \\
\text { help reduce the rate of exacerbations for patients with persistent asthma } \\
\text { who are not sufficiently controlled. }{ }^{1}\end{array}$ & \\
\hline & $\begin{array}{l}\text { - The exacerbations [mild/moderate/severe] in ICS monotherapy patients } \\
\text { result in increased resource utilisation, in terms of emergency room visits, } \\
\text { specialist visits and hospitalisations. }\end{array}$ & \\
\hline & $\begin{array}{l}\text { - A significant number of emergency room visits, hospitalisations or addi- } \\
\text { tional specialist visits due to asthma-related causes could be prevented if } \\
\text { patients' medication was escalated or adjusted in a timely manner. }\end{array}$ & $\begin{array}{l}\text { - Up to } 70-80 \% \text { of visits (emergency room, } \\
\text { specialists or hospitalisations) could be } \\
\text { avoided. }\end{array}$ \\
\hline Adherence to therapy & $\begin{array}{l}\text { - Asthma patients on ICS/LABA fixed-dose combination therapy are more } \\
\text { adherent than patients on free combination ICS + LABA which could trans- } \\
\text { late into improved treatment outcomes (e. g. better control or alleviation } \\
\text { of symptoms). }\end{array}$ & \\
\hline \multirow[t]{2}{*}{ Uncontrolled asthma } & $\begin{array}{l}\text { - A loss of asthma control translates into impairments in daily life, including } \\
\text { reduced productivity and days off work/school. Patients on monotherapy } \\
\text { lose, on average, four to five work days per year due to asthma-related } \\
\text { causes, which could be prevented if they were stepped-up to ICS/LABA } \\
\text { therapy earlier }\end{array}$ & \\
\hline & $\begin{array}{l}\text { - Uncontrolled asthma can be characterised as a progressive disease. } \\
\text { Patients on ICS who are not being sufficiently controlled should be } \\
\text { initiated earlier on ICS/LABA. }{ }^{1}\end{array}$ & \\
\hline $\begin{array}{l}\text { Stepping down } \\
\text { medication }\end{array}$ & $\begin{array}{l}\text { - A significant proportion of patients that were optimally controlled on } \\
\text { a maintenance therapy with an ICS/LABA combination experience } \\
\text { exacerbations, worsening asthma control and increased symptom load } \\
\text { when stepping down their medication therapy to ICS monotherapy. }{ }^{1}\end{array}$ & \\
\hline
\end{tabular}

${ }^{1}$ Considered in more detail in the discussion. 
Table4 Consensus statements on COPD

\begin{tabular}{|c|c|c|}
\hline & Consensus statement & Additional comments \\
\hline \multirow[t]{3}{*}{$\begin{array}{l}\text { Presenting signs } \\
\text { and symptoms }\end{array}$} & $\begin{array}{l}\text { - A typical patient that should be initiated on ICS/LABA has moder- } \\
\text { ate to severe COPD, suffers from symptoms and experiences ex- } \\
\text { acerbations. }\end{array}$ & \\
\hline & $\begin{array}{l}\text { - A significant share of COPD patients treated either with mono- } \\
\text { therapy (LABA or LAMA) or LAMA + LABA remain symptomatic } \\
\text { and these symptoms would make you consider escalating their } \\
\text { treatment }\end{array}$ & $\begin{array}{l}\text { How often the long acting bronchodilator treatment } \\
\text { needs escalation was considered to be associated with } \\
\text { the severity of the disease, using the GOLD } 2010 \text { crite- } \\
\text { ria: } 60-80 \% \text { annually in Stage } 4 \text { patients, } 40-50 \% \text { of } \\
\text { Stage } 3 \text { patients and } 5-10 \% \text { of Stage } 2 \text { patients. } \\
\text { - There no apparent difference could be detected be- } \\
\text { tween patients on LABA or LAMA monotherapy, and } \\
\text { those on LABA + LAMA. }\end{array}$ \\
\hline & $\begin{array}{l}\text { - A significant proportion of patients on monotherapy (LABA or } \\
\text { LAMA) or dual LAMA/LABA therapy do not consult you when they } \\
\text { experience worsening of symptoms or mild exacerbations that } \\
\text { would make you consider escalating their treatment. }\end{array}$ & \\
\hline Adverse effects & $\begin{array}{l}\text { - In my clinical practice, I rarely see cases of pneumonia that are } \\
\text { associated by the initiation of inhaled corticosteroids or patients } \\
\text { experiencing pneumonia during the course of their ICS treat- } \\
\text { ment. }{ }^{1}\end{array}$ & \\
\hline \multirow[t]{2}{*}{$\begin{array}{l}\text { Exacerbations } \\
\text { and worsening of } \\
\text { symptoms }\end{array}$} & $\begin{array}{l}\text { - A significant proportion of COPD patients treated either with } \\
\text { monotherapy or LABA + LAMA require emergency room visits, } \\
\text { additional specialist visits or hospitalisation each year due to ex- } \\
\text { acerbations, cough, sputum or a worsening of symptoms (e. g. } \\
\text { breathlessness). }\end{array}$ & \\
\hline & $\begin{array}{l}\text { - If medication was escalated or adjusted in a timely manner for } \\
\text { symptomatic monotherapy or LAMA+LABA patients, a signifi- } \\
\text { cant proportion of these hospital, specialist or emergency room } \\
\text { visits could be prevented. }{ }^{1}\end{array}$ & \\
\hline \multirow[t]{2}{*}{$\begin{array}{l}\text { Benefits of early } \\
\text { initiation of ICS }\end{array}$} & $\begin{array}{l}\text { - COPD patients administered ICS additional to their bronchodila- } \\
\text { tor maintenance therapy may benefit from less exacerbations, } \\
\text { better symptom control and less inflammatory processes. }\end{array}$ & \\
\hline & $\begin{array}{l}\text { - A proportion of COPD patients on monotherapy (LABA OR LAMA) } \\
\text { or LAMA + LABA combination therapy experience impairments to } \\
\text { daily life, including the loss of work days due to COPD causes; } \\
\text { these could be improved if patients were stepped-up to ICS/LABA } \\
\text { therapy earlier. }\end{array}$ & \\
\hline
\end{tabular}

${ }^{1}$ Considered in more detail in the discussion.

could lead to better compliance and improved outcomes and health care utilisation ( Table 3 ).

\section{Consensus statements on COPD}

The panellists agreed that significant proportion of their COPD patients on bronchodilator therapy presented with exacerbations that would meet the guideline recommendations for treatment escalation. It was agreed that initiation of combination ICS/ LABA therapy in a timely manner could reduce the risk of exacerbations and improve control, which would lead to reduced health care utilisation in terms of additional specialist visits, emergency room visits and hospitalisations ( $\bullet$ Table 4).

\section{Consensus statements on adherence}

The panellists agreed that poor compliance with ICS/LABA therapy resulted in worse outcomes for asthma and COPD patients. It was agreed that use of a fixed-dose ICS/LABA treatment could have a positive effect on adherence which may improve treatment outcomes and reduce health care resource utilisation (๑ Table 5).

\section{Rejected statement}

A general statement 'There's nothing better than a combination therapy if diagnosis is unclear' was felt to be correct for a number of cases of ICS/LABA therapy in obstructive lung disease, but too general to be agreed upon overall.

\section{Discussion \\ $\nabla$}

The guidelines of the NVL for asthma and COPD and the international GINA (asthma) and GOLD (COPD) have been relatively conservative on when combination therapy should be started, reasons for this include the desire to avoid overtreatment, with a consequent risk of unwanted side effects. Indeed in both COPD and asthma, specific concerns have been raised about the safety of combination therapy. Furthermore, unnecessary medications add to the already considerable costs of treating these conditions. Against this must be set the benefits of maintaining control of asthma, and reducing exacerbations in COPD. The Delphi panel examined how ICS/LABA combination therapy is used in real-life clinical practice in Germany, and how this usage accords with the conservative guideline recommendations. The panel reached consensus on 24 of the 25 statements on the use of ICS/LABA combination therapy and the results are presented in $\square$ Table 3 , - Table 4, and Table 5. This discussion considers in more detail some of the key statements. 
Table 5 General consensus statements on asthma and/or COPD

\begin{tabular}{|c|c|c|}
\hline & Consensus statement & Additional comments \\
\hline \multirow[t]{6}{*}{$\begin{array}{l}\text { Consequences of } \\
\text { non-adherence } \\
\text { to therapy }\end{array}$} & $\begin{array}{l}\text { - On average, over } 30 \% \text { of ICS/LABA patients have visited an emer- } \\
\text { gency room or seen an additional specialist over the past } 12 \text { months } \\
\text { due to non-adherence. This resource use could be reduced if these } \\
\text { patients fully adhered to their ICS/LABA dosing regimen. }{ }^{1}\end{array}$ & $\begin{array}{l}\text { - It was agreed that a fixed dose combination ICS/LABA } \\
\text { therapy could improve adherence, by } 30-40 \% \text {. }\end{array}$ \\
\hline & $\begin{array}{l}\text { - Non-adherence to monotherapy is a strong contributing factor to } \\
\text { the worsening of symptoms [over } 50 \% \text { of patients do not adhere to } \\
\text { monotherapy]. If these patients were stepped up to combination } \\
\text { treatment this could increase compliance which could in turn sig- } \\
\text { nificantly reduce the use of rescue medication and potential side } \\
\text { effects due to their inadequate use. }\end{array}$ & $\begin{array}{l}\text { - It was anticipated that for asthma patients with severe } \\
\text { exacerbations use of rescue medication could be re- } \\
\text { duced by } 50-60 \% \\
\text { - The improvement might be better in asthma than } \\
\text { COPD, since the addition of the bronchodilator, would } \\
\text { increase the patient's confidence that the agent was } \\
\text { providing relief of their condition. }\end{array}$ \\
\hline & $\begin{array}{l}\text { - Using fixed-dose ICS/LABA treatment can have a positive effect on } \\
\text { adherence which may impact treatment outcomes and reduce } \\
\text { health care resource utilisation. }\end{array}$ & \\
\hline & $\begin{array}{l}\text { - There are a significant proportion of patients with either obstruc- } \\
\text { tive pulmonary disease who cannot be specifically diagnosed as } \\
\text { COPD or asthma, or with concomitant COPD/asthma. This suggests } \\
\text { initiating these patients on ICS/LABA combination treatment from } \\
\text { the outset in order to improve airway hyper-responsiveness, cough, } \\
\text { wheezing and dyspnoea most effectively, and to improve airflow }\end{array}$ & \\
\hline & $\begin{array}{l}\text { - For a few patients there are clinical advantages to using separate } \\
\text { inhalers. Otherwise, using a fixed-dose inhaler provides better } \\
\text { treatment outcomes and therefore reduces resource utilisation. }\end{array}$ & \\
\hline & $\begin{array}{l}\text { - Early use of ICS/LABA could not only improve patient outcomes but } \\
\text { may also reduce resource use, resulting in an economic value for } \\
\text { payers. }\end{array}$ & \\
\hline
\end{tabular}

${ }^{1}$ Considered in more detail in the discussion.

\section{Use of ICS/LABA combination therapy in asthma}

The panel reached a consensus that early initiation of ICS/LABA combination therapy was appropriate when asthma patients on ICS monotherapy presented with exacerbations or breathlessness. It was, however, important to take into account the severity of exacerbations and, for example, a mild cough would not on its own be indicative of a need for combination therapy. The panel estimated that around $25 \%$ of their asthma patients presented at the practice with signs or symptoms which suggested that ICS/ LABA combination therapy should have been initiated earlier according to the NVL or GINA criteria. It was also agreed that such patients represented only a fraction of those who might benefit from combination therapy and the panel estimated that around $20-50 \%$ of asthma patients with breathing, problems, exacerbations or infections fail to mention them to their physician $(\bullet$ Table 3). These estimates are in line with figures from the European National Health and Wellness Survey, which estimated that around two-thirds of asthma patients in Germany were uncontrolled [10]. The panel reached consensus that around $30-50 \%$ of asthma patients experience two to three asthma exacerbations each year and if these were moderate or severe ICS/ LABA combination therapy should be started. Interestingly, this is a very conservative statement. Asthma guidelines suggest taking even mild exacerbations into account, since it is hard to predict whether these may develop into potentially life-threatening problems. They estimated that ICS/LABA therapy would reduce the rate of exacerbations by up to $50 \%$ and improve asthma control ( Table 3). This is in line with clinical studies that have clearly demonstrated that the addition of LABAs to a daily regimen of ICS in asthma patients reduces the number of exacerbations [15-17]. It is worthwhile noting that the panellists favoured escalation by the addition of LABAs, the option that was the minority recommendation, in the NVL guidelines, while the option of doubling the ICS dose was not generally used [1].

The panel discussed the proposition of whether asthma could be considered as a progressive disease, since long-term poor control and sustained inflammation, may lead to airway remodelling and reduced bronchial reversibility. A consensus was reached that uncontrolled asthma could be a progressive disease, but that well-controlled asthma, with ICS monotherapy or if necessary with ICS/LABA combination therapy, would be likely to remain stable for years ( $\triangle$ Table 3 ). Therefore, patients with asthma uncontrolled on ICS monotherapy should be initiated on ICS/LABA early, that is as soon as it was apparent that control was inadequate. While it is accepted that early diagnosis and effective control of asthma are likely to reduce remodelling the mechanism is unclear. There is only limited evidence that ICS reduces remodelling; a study by Ward et al. indicated that some reduction is seen on high-dose corticosteroids, but other studies have shown little evidence [18]. Another recent suggestion is that sustained bronchoconstriction leads to remodelling, which if this is the case would support the use of a LABA, in addition to the ICS, if that is insufficient to maintain control.[19]

The guidelines suggest that after asthma patients have been controlled for 3 months, consideration should be given to stepping down the dose, with the objective of maintaining control on the lowest dosage levels feasible $[4,8]$. However, the panel agreed that stepping down to ICS monotherapy by asthma patients stable on an ICS/LABA combination would lead to an increased risk of exacerbation, and that around $50 \%$ of patients stepped down to ICS monotherapy would experience more exacerbations ( $\triangle$ Table 3). A study by Bateman et al. which compared the effects of reducing the dose of ICS with that of stopping LABA in asthma patients maintained on combination therapy concluded that control was better if the LABA was retained, while the ICS dose was 
stepped down [20]. Another study by Reddel et al. also showed evidence of better maintenance of control if LABA was continued while the ICS dose was reduced [21]. Part of the rationale for stepping down has been concerns about excess asthma mortality on salmeterol, and in the USA the FDA has called for further studies on this risk [22]. A meta-analysis of 215 studies has indicated that this risk is mitigated by concurrent ICS therapy and there is no evidence that combination salmeterol/fluticasone propionate therapy is associated with an increased risk [23]. While the panel was fully aware of the controversy, there was consensus that ICS/ LABA can be continued in the longer term because of the advantages of controlled asthma; this may lead to reduced health care utilisation, for example, fewer physician visits.

\section{Use of ICS/LABA combination therapy in COPD}

For some years there was a degree of controversy over whether ICS were of benefit to COPD patients in terms of efficacy, although controlled trials have shown reduced exacerbations in COPD patients receiving ICS/LABA treatment [24-27]. A concern has been whether there is an increased risk of pneumonia associated with ICS use. The issue of clinically, but not radiologically diagnosed pneumonia first arose in a paper by Kardos et al. (2007), where the rate of pneumonia over the 44 weeks of the study was around three times higher in the ICS/LABA group than in the LABA monotherapy group (23 vs. 7 cases) [24]. The TORCH investigators also reported, in a much larger study, an increased risk of pneumonia with ICS in COPD patients $[28,29]$. Nonetheless, in both the Kardos and TORCH studies, addition of the ICS was associated with a reduced risk of exacerbations [24,26,28]. Moreover, mortality in patients with pneumonia was no worse than among those with exacerbations other than pneumonia. The panel agreed that in their practices cases of pneumonia associated with the initiation of, or during the course of ICS treatment were rare and that annually fewer than $1 \%$ of their COPD patients developed overt pneumonia ( Table 4 ). This suggests that the increased risk of pneumonia, reported with ICS in COPD patients, had not been observed in the real-life experience of the panel members.

The panel agreed that exacerbations would lead to a significant proportion of COPD patients on LABA monotherapy or LABA+ LAMA combination therapy requiring visits to the emergency room, additional specialist visits or hospitalisation and that the risk increased with disease severity ( Table 4). The panel considered that combination treatment should be initiated in a timely manner, as soon as practicable after the events, in patients with overt symptoms such as breathlessness, coughing, or infection. There was consensus that initiating combination therapy would be likely to produce a meaningful reduction in subsequent event, although estimates of how many might be prevented ranged from $10-40 \%$ ( Table 4). It is interesting to note that the panel considered that decisions to escalate to ICS/LABA would be made on both the basis of the history of exacerbations and symptoms, with GOLD stage airflow limitation just as a supporting objective factor, rather than only considering $\mathrm{FEV}_{1}$ and exacerbations.

\section{Adherence to therapy and fixed-dose combination inhalers}

An important issue in combination therapy is using a fixed-dose combination ICS/LABA inhaler, rather than separate inhalers for each agent. One clear advantage would be to improve both adherence to therapy and handling with likely consequent improve- ment in clinical outcomes. The panel agreed that over a 12month period, around $30 \%$ of patients with asthma or COPD on ICS/LABA therapy would visit an emergency room or make extra visits to a specialist because of problems arising from non-adherence to treatment, and that fixed-dose combination ICS/LABA therapy could improve adherence, by $30-40 \%$ ( Table 5).

A number of factors may contribute to improved adherence with a single fixed-dose combination device. The patient will only require one or two devices, including rescue medication. Another factor agreed on by the panel is that there tends to be better compliance with combination therapy with a single device; patients do not like taking too many 'drugs'. Moreover, asthma patients may tend to favour the inhaler that they feel is providing directly perceptible relief, usually the bronchodilator-mainly in the case of asthma, but to a lesser extent in COPD. Furthermore, a combination device reduces the potential for asthma patients to miss their maintenance dose of ICS. According to reimbursement restrictions, patients receiving ICS and LABA separately, may be given different devices when their prescription are filled, without having been trained on those devices. The co-payment for the fixed combination is lower, if compared with two separate inhalers, which in the view of the panellists can play an important role in the acceptance of the treatment.

\section{Conclusion \\ $\nabla$}

Among a panel of ten physicians working in primary and secondary care consensus was achieved on 24 out of 25 statements on the use of ICS/LABA combination therapy in the management of asthma and COPD. Most of the statements are consistent with the guidelines. However, early stopping of LABA treatment - as suggested by the FDA - in asthmatics, recently stepped up to achieve asthma control was opposed. A more liberal, symptoms- and exacerbations-based prescription of ICS/LABA combinations in COPD fits well into the new GOLD document, published after this research was done. Moreover, the agreed benefits of fixed dose ICS/LABA are congruent with both the German Society of Pneumology asthma guidelines and the FDA recommendations for asthma treatment.

\section{Acknowledgement}

$\nabla$

GlaxoSmithKline funded the study presented in this manuscript and commissioned Double Helix Consulting (DHC) to perform the research.

\section{Conflict of interest \\ $\nabla$}

Dr. Kardos and the panellists received honoraria, which were determined by DHC and in accordance with fair market value, for taking part in both phases of the study. Pulmonologists were recruited by Double Helix Consulting, by random selection from a GlaxoSmithKline list of pulmonologists practicing in Germany. There was no pre-selection of panellists by GlaxoSmithKline. Primary care physicians/general practitioners were recruited by a specialist third party agency in Germany, commissioned by Double Helix Consulting.

Mr. Bechtel, Mr. Palovis and Dr. Hagedorn report being employed by and owning stock in GlaxoSmithKline. They were involved in 
the review and revision of this manuscript only. Mr. Latif reports being employed by Double Helix Consulting, which performed the research and the assisted with the preparation of this manuscript.

\section{Institutions}

${ }^{1}$ Gemeinschaftspraxis und Zentrum für Allergologie, Pneumologie,

Schlafmedizin an der Klinik Maingau, Frankfurt am Main, Germany

${ }^{2}$ GlaxoSmithKline, Munich, Germany

${ }^{3}$ GlaxoSmithKline, Uxbridge, United Kingdom

${ }^{4}$ Double Helix Consulting, London, United Kingdom

\section{References}

1 Stock S, Redaelli M, Luengen $M$ et al. Asthma: prevalence and cost of illness. Eur Respir J 2005; 25: 47-53

2 Buist AS, McBurnie MA, Vollmer WM et al. International variation in the prevalence of COPD (the BOLD Study): a population-based prevalence study. Lancet 2007; 370: $741-750$

3 Geldmacher $H$, Biller $H$, Herbst $A$ et al. The prevalence of chronic obstructive pulmonary disease (COPD) in Germany. Results of the BOLD study. Dtsch Med Wochenschr 2008; 133: 2609-2614

4 Bundesärztekammer (BÄK), Kassenärztliche Bundesvereinigung (KBV), Arbeitsgemeinschaft der Wissenschaftlichen Medizinischen Fachgesellschaften (AWMF). Nationale VersorgungsLeitlinien Asthma - Langfassung. 2011: Version 1.3 2: Available from: http://www.versorgungsleitlinien.de/themen/asthma [Last accessed 27/03/2012]

5 Bundesärztekammer (BÄK), Kassenärztliche Bundesvereinigung (KBV), Arbeitsgemeinschaft der Wissenschaftlichen Medizinischen Fachgesellschaften (AWMF). Nationale VersorgungsLeitlinien. COPD Langfassung. Version 1.9 2012: Available from: http://www.versorgungsleitlinien.de/themen/COPD [Last accessed 27/03/2012]

6 Buhl R, Berdel D, Críee CP et al. Guidelines for the diagnosis and treatment of asthma patients, German Airways League \& German Respiratory Society. Pneumologie 2006; 60: 139-180

7 Vogelmeier C, Buhl R, Ciée CP et al. Guidelines for the diagnosis and therapy of COPD Issued by Deutsche Atemwegsliga and Deutsche Gesellschaft für Pneumologie und Beatmungsmedizin. Pneumologie 2007; 61: e1 - e40

8 Global Initiative for Asthma (GINA). Global strategy for asthma management. Updated December 2010 Available at: http://www.ginasthma.org/guidelines-gina-report-global-strategy-for-asthma.html [Last accessed 27/03/2012

9 Global Initiative for Chronic Obstructive Lung Disease (GOLD). Global Strategy for the diagnosis and management and prevention of chronic pulmonary disease. updated 2011 Available at: http://www.goldcopd. org/guidelines-global-strategy-for-diagnosis-management.html [Last accessed 27/03/2012]

10 Demoly P, Paggiaro P, Plaza V et al. Prevalence of asthma control among adults in France, Germany, Italy, Spain and the UK. Eur Respir Rev 2009; 18: 105-112

11 Nathan RA, Sorkness CA, Kosinski $M$ et al. Development of the asthma control test: a survey for assessing asthma control. J Allergy Clin Immunol 2004; 113: 59-65
12 GlaxoSmithline. FACHINFORMATION Viani® Diskus ${ }^{\circledR}$. 2011: http:// www.fachinfo.de/data/fi/jsearch?praep [Last accessed 03/04/2012]

13 Dalkey N. An experimental study of group opinion: the Delphi method. Futures 1969; 1: 408-426

14 Thompson M. Considering the implication of variations within Delphi research. Fam Pract 2009; 26: 420-424

15 Pauwels RA, Löfdahl CG, Postma DS et al. Effect of inhaled formoterol and budesonide on exacerbations of asthma. Formoterol and Corticosteroids Establishing Therapy (FACET) International Study Group. N Engl J Med 1997; 337: 1405-1411

16 Ducharme FM, Ni Chroinin M, Greenstone I et al. Addition of long-acting beta2-agonists to inhaled corticosteroids versus same dose inhaled corticosteroids for chronic asthma in adults and children (Review). Cochrane Database of Systematic Reviews 2010: Art. No.: CD005535 5: DOI 10.1002/14651858.CD005535.pub2

17 Sin DD, Man J, Sharpe $H$ et al. Pharmacological management to reduce exacerbations in adults with asthma: a systematic review and metaanalysis. JAMA 2004; 292: 367-376

18 Ward C, Pais M, Bish $R$ et al. Airway inflammation, basement membrane thickening and bronchial hyperresponsiveness in asthma. Thorax 2002; 57: 309-316

19 Grainge CL, Lau LC, Ward JA et al. Effect of bronchoconstriction on airway remodeling in asthma. N Engl J Med 2011; 364: 2006 - 2015

20 Bateman ED, Jacques L, Goldfrad C et al. Asthma control can be maintained when fluticasone propionate/salmeterol in a single inhaler is stepped down. J Allergy Clin Immunol 2006; 117: 563-570

21 Reddel HK, Gibson PG, Peters MJ et al. Down-titration from high-dose combination therapy in asthma: Removal of long-acting beta(2)-agonist. Respir Med 2010; 104: 1110-1120

22 Chowdhury BA, Dal Pan G. The FDA and safe use of long-acting betaagonists in the treatment of asthma. N Engl J Med 2010; 362: 11691171

23 Weatherall $M$, Wijesinghe $M$, Perrin $K$ et al. Meta-analysis of the risk of mortality with salmeterol and the effect of concomitant inhaled corticosteroid therapy. Thorax 2010; 65: 39-43

24 Kardos P, Wencker M, Glaab T et al. Impact of salmeterol/fluticasone propionate versus salmeterol on exacerbations in severe chronic obstructive pulmonary disease. Am J Respir Crit Care Med 2007; 175: $144-149$

25 Szafranski W, Cukier A, Ramirez A et al. Efficacy and safety of budesonide/formoterol in the management of chronic obstructive pulmonary disease. Eur Respir J 2003; 21: 74-81

26 Calverley P, Pauwels R, Vestbo J et al. Combined salmeterol and fluticasone in the treatment of chronic obstructive pulmonary disease: a randomised controlled trial. Lancet 2003; 361: 449-456

27 Yang IA, Fong KM, Sim EH et al. Inhaled corticosteroids for stable chronic obstructive pulmonary disease. Cochrane Database Syst Rev 2007: CD002991

28 Calverley PMA, Anderson JA, Celli B et al. Salmeterol and fluticasone propionate and survival in chronic obstructive pulmonary disease. $\mathrm{N}$ Eng J Med 2007; 356: 775 - 789

29 Crim C, Calverley PM, Anderson J et al. Pneumonia in patients receiving inhaled glucocorticoids alone or in combination. TORCH Study Results. Eur Respiratory J 2009; 34: 641 -647 